\title{
COVID-19 PANDEMIC QUARANTINE AND SOCIAL JETLAG
}

\author{
M. SAHRAEI ${ }^{1}$, G. H. MEFTAHI ${ }^{2}$, H. SAHRAEI ${ }^{2 凶}$ \\ ${ }^{1}$ School of Dentistry, Shahid Beheshti University of Medical Science, Tehran, Iran; \\ ${ }^{2}$ Neuroscience Research Center, Baqiyatallah University \\ of Medical Sciences, Tehran, Iran; \\ 凶e-mail: h.sahraei@bmsu.ac.iror hsahraei1343@gmail.com
}

Received: 31 January 2021; Accepted: 22 September 2021

Covid-19 pandemic forced the governments to choose the policy to the lockdown the gathering centers, including universities and schools to prevent the rapid spread of the disease, forcing millions of people to stay at home for several weeks and even more. Staying in the home for such long periods is associated with a change in the wake/sleep period (a kind of social jet lag) and the resulting alteration in feeding time and type of food. Moreover, the prevalence of anxiety and depression resulted from the reduction in physical activity and bad news also may help to worsen the social jetlag effect on these parts of society. Possible hazardous changes in this factor are reviewed in this study and some suggestions for better management of this condition are also offered. Pubmed, SCOPUS, WOS, and Google Scholar data banks were searched using the following keyword in combination and/or alone: jetlag, social jetlag, Chronobiology, photoperiod, metabolic disease, cardiovascular, sleep/weak period. Longtime lockdown gathering centers are shown to change the photoperiod cycle in people, and it may induce several consequences, including the effects on cognitive brain function, induce mental illness, metabolic syndrome, insulin resistance, mitochondrial aging, and cardiovascular diseases. Considering these facts, it is important to make rehabilitation programs for all the societies' members for post-pandemic time.

Ke y w o rd s: Covid-19, forced lockdown, social jetlag, depression, metabolic disturbances, anxiety, obesity.

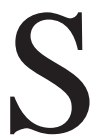
ince October 2019, which the Severe acute respiratory syndrome coronavirus 2 (SARSCoV-2) was identified as the new SARS Coronavirus, the rate of infection and also total death from this new virus produced a global horror worldwide and forced the governments to make different and difficult decisions about their societies for saving their societies [1, 2]. These decisions, including a lockdown of economic and instructive activities, forced millions of young people to stay at home for several weeks [3]. These decisions were chosen because there were no solutions for disease cure (no vaccine and/or drug for the treatment of the virus), and it was essential for inhibition of rapid disease transmission [4], which was beyond the capacity of health systems to deal with the growing wave of hospital admissions. For several weeks, staying at home can severely shift the weak/sleep duration in the youth people [5]. The human is considered to be morning and/or evening activity [6, 7], which is shown to be regulated by the clock genes located in the neurons within the suprachiasmatic nucleus in the hypothalamus [8]. Disruption of photoperiod and/or the time of the work (e.g., shift working in the factories), namely classified as jetlag and social jetlag, respectively [9], can lead to a broad spectrum of metabolism malfunction [10], cardiovascular disease [9], and neural disease [5, 11, 12]. Social jetlag is first mentioned by the factory workers whose shift was changed to the evening, and they must work when they were asleep in their everyday life [5]. However, recently the researchers have considered another type of social jetlag in people. They emphasize that weekend holidays and long-term New Year holidays can influence the photoperiod activity of the youth so that they show a shift in their weak/sleep activity

(C) 2021 Sahraei M. et al. This is an open-access article distributed under the terms of the Creative Commons Attribution License, which permits unrestricted use, distribution, and reproduction in any medium, provided the original author and source are credited. 
[5]. The Covid-19 lockdown of the universities and schools led to a long-term holiday-like condition of people, which may induce a severe health condition of this part of the population. In this review, first, we show how social jetlag (a direct result of the socalled stay-at-home policy) may act as a stressor to metabolic, cardiovascular, and neuronal disease induction. Second, the possible ways of overcoming this condition are offered.

\section{Methodological aspects}

Data Banks. In this review, several data banks were used. Pubmed, SCOPUS, WOS, and Google Scholar were searched using the following keyword (in combination and/or alone): Jetlag, social jetlag, chronobiology, photoper anxiety iod, metabolic disease, cardiovascular, sleep/weak period. In combination, we use the words 'with, and, or'. Also, we use Systematic Review, Meta-Analysis, and Review, for furthering filtering of the data. At last, the time window was years 2000-2021.

Results. A total of 112 review articles were founded after a comprehensive search of the data banks. Among these articles, 43 articles were considering because of fulfilling our inclusion criteria. Moreover, all the articles considering the psychological effects of Covid-19 and Covid-19 signs and symptoms were considered.

\section{The impact of Covid-19 lockdown on circadian rhythm}

There are scanty studies concerning the effects of lockdown on change in circadian rhythm and its hazardous effects on metabolic status. However, in one study, Bagci and colleagues (2020) have emphasized that chronic photoperiod change during lockdown may dramatically affect different organs of the fetus body during its development [13]. According to the previous studies, chronic changes during the daytime photoperiod are enhanced by artificial light during nighttime [8]. Change in photoperiod, as indicated by the longtime light exposure which occurred in lockdown during Covid-19, may alter the function of all body organs, according to Bagic et al. [13]. However, several questions are arising in this regard. First, which hormonal changes occurred during the lockdown in response to photoperiod change? Second, how these hormonal changes can affect the body organs such as the heart, lungs, kidneys, and especially the brain? Tired of these alterations remain for a while? Forth, if there may be some epi- genetic changes at the cellular level? Moreover, stile other questions also may be existing in this regard.

\section{Social jetlag and metabolic disturbance}

Data indicated that some metabolic functions, including blood glucose level and insulin secretion from the pancreatic beta cells, are synchronized with variation in plasma melatonin level [14]. In this regard, data indicated that blood glucose level is under the suprachiasmatic nucleus (SCN) in the hypothalamus and the circadian activity of the pancreas, liver, skeletal muscles, and white adipose tissue [13]. According to these data, social jetlag, most prevalent in modern societies on the metabolic malfunction, is mentioned in several articles in the past few years [15]. On the other hand, there is a strong link between metabolic dysfunction and the severity of Covid-19 [16]. This interrelationship indicated that focus on the metabolic disturbance during Covid-19 a lockdown may play a critical role in reducing the Covid-19 side effects on society's health. In this regard, we will focus on the primary metabolic disturbance induced by photoperiod change, including insulin function, glucose metabolism, obesity, and aging due to insulin resistance and glucose metabolism disturbance.

\section{Social jetlag and insulin resistance}

Insulin resistance is defined as a reduction of insulin function in the brain and periphery [17]. Insulin resistance may occur when the photoperiod cycle is removed by shift working [18] or staying in the artificial light, especially at home during nighttime, dramatically changing the normal light/dark cycle [13]. On the other hand, it is shown that increasing the melatonin hormone during the dark phase of the photoperiod cycle has a modulation influence on insulin receptor sensitivity in different organs [19]. According to these data, it is not surprising that changes in photoperiod can influence the hormonal status and induce several metabolic disturbances, including insulin resistance [15]. However, insulin resistance can induce several diseases such as brain cognition deficit, eating behavior and obesity, and anxiety and depression [17]. It must be noticed that the psychological problems associated with Covid-19 lockdown are one of the most frequent signs in home residents $[11,20]$. In this regard, it is postulated that food composition and amount, physical activity, and fin control of sleep/wake duration during lockdown may help for the metabolic disturbance induced by photoperiod changes [20]. 


\section{Social jetlag and glucose metabolism}

As mentioned above, the change in the photoperiod cycle in the Covid-19 lockdown may influence the melatonin plasma level and induce insulin resistance [17]. One of the most critical signs of insulin resistance is glucose intolerance, defined as the height of plasma glucose level after a glucose tolerance test. Cellular and molecular details of glucose intolerance are suggested elsewhere [21]. In this regard, it is essential to be noticed that glucose entered into the target cells (skeletal muscle cells, liver cells, and white adipose tissue cells) via an insulin receptor-mediated mechanism [8]. Furthermore, as mentioned above, the insulin receptors and insulin function are modulated by the high melatonin level during the dark phase of the photoperiod [19]. Therefore, as predicted, shortening the dark phase of the photoperiod during Covid-19 lockdown may induce and/or enhance the modulation effect of melatonin on insulin function and, at last, induces insulin resistance and glucose intolerance [22].

\section{Social jetlag and obesity}

One of the consequences of insulin resistance and glucose intolerance is obesity [22]. Abdominal fat, which is defined as glucose and lipid abnormal metabolism, is the main sign of obesity [23]. This sign is shown to be frequently in the shift workers and other personnel who have to work in the dark phase of the photoperiod [24]. However, no study focuses on the effects of social jetlag induced by lockdown during the Covid-19 pandemic [12]. In other words, because of the importance of obesity as the resulted sign of insulin resistance and glucose intolerance [18], on one hand, and the gap in our knowledge in this regard, on the other hand, the studies dealing with the effects of Covid-19 lockdown on obesity should come into focus as soon as possible [25].

\section{Social jetlag and aging}

Aging is considered the malfunction of the hormonal systems, especially those dealing with metabolism [15, 26]. According to the new hypothesis, aging is a reduction in the ability of the cell mitochondria for ATP production because of the damaging effects of stress hormones on its DNA and reduction of mitochondrial DNA for reproduction [27, 28]. As a result, the electron chain system within the mitochondrial wall became dam- aged [29]. The aged mitochondria cannot produce enough ATP needed for all cellular functions, including protein synthesis, gene duplication, gene and protein expression, and cell regeneration. The result of these failures is defined as aging. As mentioned in the above parts in this section, disrupted photoperiod [30], which is the character of the social jetlag including the Covid-19 lockdown, can increase the hypothalamus-pituitary-adrenal axis (HPA axis) and increase the cortisol plasma level in the stress suffered victims [31]. One of the essential effects of stress-induced aging is that those parts of the brain involved in cognitive function, including the hippocampus, the amygdala, and the frontal cortex, exhibit morphological and functional alterations [32]. The hazardous problem that can occur during the Covid-19 lockdown photoperiod change on aging may also have a high value for the governors [33].

\section{Social jetlag and brain function}

The brain is the main organ for the response to stress [34], and chronic stress can damage the brain structures, including the hippocampus and frontal cortex [32]. Since the abnormal change in the photoperiod cycle is considered a negative stressor [35], it is not out of mind that abnormal photoperiod change may affect brain function, especially those categorized as cognitive functions. Several data exist which indicated the importance of the photoperiod phenotype of brain function (for rev see: Correa, et al. 2020 [36]). In addition, it is shown that photoperiod change can induce insulin resistance in the brain [10, 30, 37]. Insulin resistance in the brain is considered one of the leading causes of cognitive deficit [38]. The central brain region which is thought to be responsible for cognitive dysfunction in response to stress is the hippocampus [39, 40].

Although photoperiod cycle change can induce cognitive function deficit, it is also essential that photoperiod change can induce hippocampal shrinkage [41, 42]. Hippocampal shrinkage is also the main basis for several mental diseases, including anxiety and depression [43, 44]. According to previous studies, photoperiod cycle change can induce anxiety and depression in young and older people $[45,46]$. Because stress disorders may lead to a failure chain that may end with suicide [47], it is also a hazardous problem that must be resolved in the pandemic lockdown. However, it is no clear if photoperiod change induced by Covid-19 lockdown can influence cognitive function or not? Researches 
in this area can help the governors to address the hazards of longtime photoperiod cycle change.

\section{Social jetlag and cardiovascular system function}

The cardiovascular system is shown to be affected during the photoperiod cycle change [48]. It is now clear that a shift in the photoperiod cycle can interact with hormonal body pattern, increase the glucose plasma level at the time that the body did not need, and increases several adipokines, including leptin and adiponectin, in the plasma that can impair the lipid metabolism and in turn induce dyslipidemia and vascular diseases including coronary artery disease [10, 12, 49, 50]. Moreover, disruption of the light/dark cycle can interact with peripheral and central clock cells and induce cardiac dysfunction and cardiac arrest $[9,29,51]$. The severity of cardiovascular dysfunction is shown in the mortality of cardiac attacks in shift workers [48]. As mentioned in the above sections, there is no study dealing with the effects of photoperiod cycle change resulting from Covid-19 pandemic lockdown on cardiovascular system dysfunction in young people, and it is also among the most important studies that should be done.

Conclusion remarks. Jetlag and social jetlag are associated with several hazardous consequences on societies [26], which are well discussed in huge research and review articles. For example, the incidence of Covid-19 and its mortality and morbidity has forced governments worldwide to lockdown the gathering centers, including the schools and universities, to reduce the social contact and reduce the number of Covid-19 suffered as a result [13, 52]. However, the longtime lockdown is shown to change the photoperiod cycle in people, and it may induce several consequences, including the effects on cognitive brain function, induce mental illness, metabolic syndrome, insulin resistance, mitochondrial aging, and cardiovascular diseases. Considering these facts, it is essential to make rehabilitation programs for all the societies' members, especially the youth and older people, for post-pandemic time. In addition, studies also needed to clarify the impact of Covid-19 lockdown-induced photoperiod cyclical change in healthy people. Thus, it seems that the effects of the holidays caused by the Covid-19 pandemic may lead to metabolic problems and even obesity, which may increase the risk of severe Covid-19 disease if a person becomes infected. To reduce such a problem, health policy-makers and planners should consider strategies for creating physical activity at home or in the quarantine area, nutrition control programs, and provide programs to regulate the sleep-wake cycle.

Conflict of interest. Authors have completed the Unified Conflicts of Interest form at http://ukrbiochemjournal.org/wp-content/uploads/2018/12/ coi_disclosure.pdf and declare no conflict of interest.

Acknowledgments. We want to express our gratitude to Dr. Homeira Zardooz for her comments on the topics of this article.

\section{ПАНДЕМІЯ COVID-19 TA СОЦІАЛЬНИЙ ДЖЕТЛАГ}

\section{Sahraei ${ }^{1}$, G. H. Meftahi², H. Sahraei ${ }^{2 \bowtie}$}

${ }^{1}$ School of Dentistry, Shahid Beheshti University of Medical Science, Tehran, Iran;

${ }^{2}$ Neuroscience Research Center, Baqiyatallah University of Medical Sciences, Tehran, Iran; 凶e-mail: h.sahraei@bmsu.ac.ir or hsahraei1343@gmail.com

Пандемія Covid-19 змусила уряди багатьох країн вибрати політику щодо закриття місць колективного перебування людей, зокрема університетів і шкіл, для запобігання поширення хвороби. Це змусило мільйони людей залишатися вдома протягом декількох тижнів і навіть більше. Перебування вдома протягом тривалих періодів часто призводить до збою циклів сну та неспання (свого роду соціальний джетлаг) i пов'язаного з цим зсуву у часі приймання їжі та зміни типу їжі. Крім того, підвищена тривожність і депресія, спричинені зниженням фізичної активності та поганими новинами, також можуть посилити соціальний джетлаг. У цьому дослідженні розглянуто можливі небезпечні наслідки таких змін, а також запропоновані деякі пропозиції щодо ефективнішого управління такою ситуацією. Пошук в базах даних Pubmed, SCOPUS, WOS i Google Scholar проводили за такими ключовими словами: джетлаг, соціальний джетлаг, хронобіологія, фотоперіод, метаболічні та серцево-судинні захворювання, цикл сну/активності. Показано, що тривале закриття місць колективного перебування змінює життєві цикли людей, і це може впливати на когнітивні функції мозку, спричинювати психічні захворювання, метаболічний синдром, резистентність до інсуліну, старіння мітохондрій та серцево- 
судинні захворювання. 3 огляду на ці факти важливо розробити реабілітаційні програми для всіх членів суспільства на постпандемічний період.

К л ю ч о в і с ло в а: COVID-19, вимушена ізоляція, соціальний джетлаг, депресія, метаболічні порушення, тривога, ожиріння.

\section{References}

1. Prather KA, Wang CC, Schooley RT. Reducing transmission of SARS-CoV-2. Science. 2020; 368(6498): 1422-1424.

2. Meftahi GH, Z. Bahari Z, Jangravi Z, Iman M. A vicious circle between oxidative stress and cytokine storm in acute respiratory distress syndrome pathogenesis at COVID-19 infection. Ukr Biochem J. 2021; 93(1): 18-29.

3. Silver RC. Surviving the trauma of COVID-19. Science. 2020; 369(6499): 11.

4. Romagnoli S, Peris A, De Gaudio AR, Geppetti P. SARS-CoV-2 and COVID-19: From the Bench to the Bedside. Physiol Rev. 2020; 100(4): 1455-1466.

5. Henderson SEM, Brady EM, Robertson N. Associations between social jetlag and mental health in young people: A systematic review. Chronobiol Int. 2019; 36(10): 1316-1333.

6. Roenneberg T, Pilz LK, Zerbini G, Winnebeck EC. Chronotype and Social Jetlag: A (Self-) Critical Review. Biology (Basel). 2019; 8(3): 54.

7. Tsang $\mathrm{AH}$, Astiz M, Friedrichs M, Oster H. Endocrine regulation of circadian physiology. $J$ Endocrinol. 2016; 230(1): R1-R11.

8. Challet E. Keeping circadian time with hormones. Diabetes Obes Metab. 2015; 17(Suppl 1): 76-83.

9. Hernández-García J, Navas-Carrillo D, OrenesPiñero E. Alterations of circadian rhythms and their impact on obesity, metabolic syndrome and cardiovascular diseases. Crit Rev Food Sci Nutr. 2020; 60(6): 1038-1047.

10. Mason IC, Qian J, Adler GK, Scheer FAJL. Impact of circadian disruption on glucose metabolism: implications for type 2 diabetes. Diabetologia. 2020; 63(3): 462-472.

11. Brooks SK, Webster RK, Smith LE, Woodland L, Wessely S, Greenberg N, Rubin GJ. The psychological impact of quarantine and how to reduce it: rapid review of the evidence. Lancet. 2020; 395(10227): 912-920.
12. Mota MC, Silva CM, Balieiro LCT, Fahmy WM, Crispim CA. Social jetlag and metabolic control in non-communicable chronic diseases: a study addressing different obesity statuses. Sci Rep. 2017; 7(1): 6358.

13. Bagci S, Sabir H, Müller A, Reiter J. Effects of altered photoperiod due to COVID-19 lockdown on pregnant women and their fetuses. Chronobiol Int. 2020; 37(7): 961-973.

14. Bruckdorfer KR, Kang SS, Khan IH, Bourne AR, Yudkin J. Diurnal changes in the concentrations of plasma lipids, sugars, insulin and corticosterone in rats fed diets containing various carbohydrates. Horm Metab Res. 1974; 6(2): 99-106.

15. Kim TW, Jeong JH, Hong SC. The impact of sleep and circadian disturbance on hormones and metabolism. Int J Endocrinol. 2015; 2015: 591729.

16. Bornstein SR, Dalan R, Hopkins D , Mingrone G, Boehm BO. Endocrine and metabolic link to coronavirus infection. Nat Rev Endocrinol. 2020; 16(6): 297-298.

17. Heni M, Kullmann S, Preissl H, Fritsche A, Häring HU. Impaired insulin action in the human brain: causes and metabolic consequences. Nat Rev Endocrinol. 2015; 11(12): 701-711.

18. Shi SQ, Ansari TS, McGuinness OP, Wasserman DH, Johnson CH. Circadian disruption leads to insulin resistance and obesity. Curr Biol. 2013; 23(5): 372-381.

19. Owino S, Sánchez-Bretaño A, Tchiov C, Cecon E, Karamitri A, Dam J, Jockers R, Piccione G, Noh HL, Kim T, Kim K, Baba K, Tosini G. Nocturnal activation of melatonin receptor type 1 signaling modulates diurnal insulin sensitivity via regulation of PI3K activity. $J$ Pineal Res. 2018; 64(3): e12462.

20. Shahyad S, Mohammadi MT. Psychological impacts of Covid-19 outbreak on mental health status of society individuals: a narrative review. J Mil Med. 2020; 22(2): 184-192.

21. Briançon-Marjollet A, Weiszenstein M, Henri M, Thomas A, Godin-Ribuot D, Polak J. The impact of sleep disorders on glucose metabolism: endocrine and molecular mechanisms. Diabetol Metab Syndr. 2015; 7: 25.

22. Qian J, Scheer FAJL. Circadian System and Glucose Metabolism: Implications for Physiology and Disease. Trends Endocrinol Metab. 2016; 27(5): 282-293. 
23. Roenneberg $\mathrm{T}$, Allebrandt $\mathrm{KV}$, Merrow $\mathrm{M}$, Vetter C. Social jetlag and obesity. Curr Biol. 2012; 22(10): 939-943.

24. Mathew GM, Hale L, Chang AM. Social jetlag, eating behaviours and BMI among adolescents in the USA. Br J Nutr. 2020; 124(9): 979-987.

25. Parsons MJ, Moffitt TE, Gregory AM, GoldmanMellor S, Nolan PM, Poulton R, Caspi A. Social jetlag, obesity and metabolic disorder: investigation in a cohort study. Int J Obes (Lond). 2015; 39(5): 842-848.

26. Cao Y, Wang RH. Associations among metabolism, circadian rhythm and ageassociated diseases. Aging Dis. 2017; 8(3): 314333.

27. Eisner V, Picard M, Hajnóczky G. Mitochondrial dynamics in adaptive and maladaptive cellular stress responses. Nat Cell Biol. 2018; 20(7): 755765.

28. Picard M, McEwen BS, Epel ES, Sandi C. An energetic view of stress: Focus on mitochondria. Front Neuroendocrinol. 2018; 49: 72-85.

29. Makrecka-Kuka M, Liepinsh E, Murray AJ, Lemieux H, Dambrova M, Tepp K, Puurand M, Käämbre T, Han WH, de Goede P, O'Brien KA, Turan B, Tuncay E, Olgar Y, Rolo AP, Palmeira CM, Boardman NT, Wüst RCI, Larsen TS. Altered mitochondrial metabolism in the insulin-resistant heart. Acta Physiol (Oxf). 2020; 228(3): e13430.

30. Ruiz-Gayo M, Olmo ND. Interaction Between Circadian Rhythms, Energy Metabolism, and Cognitive Function. Curr Pharm Des. 2020; 26(20): 2416-2425.

31. McEwen BS, Gray JD, Nasca C. 60 Years of Neuroendocrinology: Redefining neuroendocrinology: stress, sex and cognitive and emotional regulation. $J$ Endocrinol. 2015; 226(2): T67-T83.

32. McEwen BS. Effects of adverse experiences for brain structure and function. Biol Psychiatry. 2000; 48(8): 721-731.

33. Ellwanger JH, Lekgoathi MDS, Nemani K, Tarselli MA, Al Harraq A, Uzonyi A, DuttonRegester K, Yoho R, Srivastava S, Strong M, Li Y, Fu J, Waiho K, Beltrán IM, Mukherjee A, Brunet TDP. News from a postpandemic world. Science. 2020; 369(6499): 26-29.

34. McEwen BS. Physiology and neurobiology of stress and adaptation: central role of the brain. Physiol Rev. 2007; 87(3): 873-904.
35. Nelson R, Martin L. Seasonal changes in stress responses. Stress Science: Neuroendocrinol. 2010; 440.

36. Correa A, Alguacil S, Ciria LF, Jiménez A, Ruz M. Circadian rhythms and decisionmaking: a review and new evidence from electroencephalography. Chronobiol Int. 2020; 37(4): 520-541.

37. Luo Q, Xiao Y, Alex A, Cummins TR, Bhatwadekar AD. The Diurnal Rhythm of Insulin Receptor Substrate-1 (IRS-1) and Kir4.1 in Diabetes: Implications for a Clock Gene Bmal1. Invest Ophthalmol Vis Sci. 2019; 60(6): 1928-1936.

38. Biessels GJ, Reagan LP. Hippocampal insulin resistance and cognitive dysfunction. Nat Rev Neurosci. 2015; 16(11): 660-671.

39. Kim JJ, Diamond DM. The stressed hippocampus, synaptic plasticity and lost memories. Nat Rev Neurosci. 2002; 3(6): 453-462.

40. Faraji N, Shiravi A, Bahari Z, Shirvani H, Meftahi GH. Basolateral amygdala $\alpha 1$ adrenergic receptor suppression attenuates stress-induced anxiety-like behavior and spine morphology impairment on hippocampal CA1 pyramidal neurons. Neurochem J. 2020; 14(1): 77-89.

41. Cho K. Chronic 'jet lag' produces temporal lobe atrophy and spatial cognitive deficits. Nat Neurosci. 2001; 4(6): 567-568.

42. Zhang F, Li W, Li H, Gao S, Sweeney JA, Jia Z, Gong $Q$. The effect of jet lag on the human brain: A neuroimaging study. Hum Brain Mapp. 2020; 41(9): 2281-2291.

43. Hosseinmardi L, Shiravi A, Meftahi GH, Afarinesh MR. Inactivation of $\beta 1$-adrenergic receptor in the basolateral amygdala nucleus attenuated anxiety-like behaviour in response to foot-shock stress in the male rat. Physiol Pharmacol. 2019; 23(2): 101-114.

44. Czéh B, Lucassen PJ. What causes the hippocampal volume decrease in depression? Eur Arch Psychiatry Clin Neurosci. 2007; 257(5): 250-260.

45. Mathew GM, Hale L, Chang AM. Sex Moderates Relationships Among School Night Sleep Duration, Social Jetlag, and Depressive Symptoms in Adolescents. $J$ Biol Rhythms. 2019; 34(2): 205-217.

46. Norbury R. Chronotype, depression and hippocampal volume: cross-sectional associa- 
tions from the UK Biobank. Chronobiol Int. 2019; 36(5): 709-716.

47. Le-Niculescu H, Roseberry K, Levey DF, Rogers J, Kosary K, Prabha S, Jones T, Judd S, McCormick MA, Wessel AR, Williams A, Phalen PL, Mamdani F, Sequeira A, Kurian SM, Niculescu AB. Towards precision medicine for stress disorders: diagnostic biomarkers and targeted drugs. Mol Psychiatry. 2020; 25(5): 918-938.

48. Khan S, Malik BH, Gupta D, Rutkofsky I. The Role of Circadian Misalignment due to Insomnia, Lack of Sleep, and Shift Work in Increasing the Risk of Cardiac Diseases: A Systematic Review. Cureus. 2020; 12(1): e6616.

49. Mota MC, Silva CM, Balieiro LCT, Gonçalves BF, Fahmy WM, Crispim CA. Association between social jetlag food consumption and meal times in patients with obesity-related chronic diseases. PLoS One. 2019; 14(2): e0212126.

50. Wong PM, Hasler BP, Kamarck TW, Muldoon MF, Manuck SB. Social Jetlag, Chronotype, and Cardiometabolic Risk. J Clin Endocrinol Metab. 2015; 100(12): 4612-4620.

51. Taguchi A, Ohta Y, Tanizawa Y. Molecular clock as a regulator of $\beta$-cell function. $J$ Diabetes Investig. 2018; 9(3): 453-456.

52. Dobson AP, Pimm SL, Hannah L, Kaufman L, Ahumada JA, Ando AW, Bernstein A, Busch J, Daszak P, Engelmann J, Kinnaird MF, Li BV, Loch-Temzelides $T$, Lovejoy $T$, Nowak $K$, Roehrdanz PR, Vale MM. Ecology and economics for pandemic prevention. Science. 2020; 369(6502): 379-381. 